\title{
Estimating Nitrogen Mineralization of Composted Poultry Manure, Organic Fertilizers, and Green Manure Crops for Organic Sweet Corn Production on a Sandy Soil Under Laboratory Conditions
}

\author{
Heidi J. Johnson ${ }^{1,3}$, Jed B. Colquhoun ${ }^{1}$, Alvin J. Bussan ${ }^{1}$, and \\ Carrie A.M. Laboski
}

\begin{abstract}
AdDitional INDEX WORDS. alfalfa, pea, rye
SuMMARY. Organic sweet corn (Zea mays) production is challenging for growers because of the high nitrogen $(\mathrm{N})$ requirements of sweet corn and the relatively low $\mathrm{N}$ content of organic soil amendments. Total $\mathrm{N}$ supplied and rate of mineralization throughout the growing season are two important aspects in determining the optimal $\mathrm{N}$ management program. Green manure ( $\mathrm{GrM})$ crops, composted manures, and commercially available organic fertilizers are used to manage $\mathbf{N}$ in organic production systems. Using a combination of these tactics can optimize $\mathbf{N}$ while minimizing cost. In this study, we used combinations of composted poultry manure (CPM) and two organic fertilizers (one high $\mathrm{N}$ and one with a balance of nutrients) with three GrM crops [rye (Secale ceveale), alfalfa (Medicago sativa), and pea (Pisum sativum)] in a loamy sand soil for a 112-day laboratory incubation study. Total plant available $\mathbf{N}$ (PAN) was quantified at six times throughout the 16 weeks to determine total $\mathrm{N}$ mineralized and rate of $\mathrm{N}$ release from each of the management programs. The CPM and the high $\mathrm{N}$ organic fertilizer mineralized completely within the first 6 weeks of the study, while only $65 \%$ of the other organic fertilizer mineralized by the end of the study. Total $\mathrm{N}$ mineralized from pea grown as a GrM for 48 days was comparable to the amount of $\mathrm{N}$ mineralized from rye suggesting that pea as a GrM crop should not receive an $\mathrm{N}$ credit in field production on a sandy soil. Significant quantities of PAN were mineralized from alfalfa residue, the equivalent of $80 \mathrm{lb} /$ acre, although this is not sufficient for sweet corn production. The combination of alfalfa and the high $\mathbf{N}$ organic fertilizer provided sufficient $\mathbf{N}$ for sweet corn production and the mineralization rate closely matched sweet corn need. The release of $\mathrm{N}$ from CPM, even in combination with GrM crops, was asynchronous with sweet corn crop need.
\end{abstract}

$\mathrm{N}$ itrogen management for optimal crop production is one of the most difficult and costly practices in organic agriculture. The majority of the $\mathrm{N}$ in organic sources is bound in organic compounds, which must be mineralized by the soil microbial community to become a PAN form (ammonium or nitrate). Moisture, temperature, and composition of the soil microbe community can affect the rate at which organic $\mathrm{N}$ is mineralized. Total $\mathrm{N}$ content of organic sources is often not completely mineralized within one growing season (Crew and Peoples, 2005; Hartz et al., 2000; Hartz and Johnstone, 2006).

${ }^{1}$ Department of Horticulture, University of Wisconsin Madison, 1575 Linden Drive, Madison, WI 53706

${ }^{2}$ Department of Soil Science, University of Wisconsin Madison, 1525 Observatory Drive, Madison, WI 53706 ${ }^{3}$ Corresponding author. E-mail: heidi.johnson@ces. uwex.edu.
Insufficient PAN in the soil during periods of high crop need can translate into crop deficiency and potentially yield loss. However, excessive PAN in the soil before crop need or at times of low crop $\mathrm{N}$ use can leave the nitrate portion susceptible to leaching and inefficient crop use. Ideally, the mineralization rate would match fluctuations in crop need throughout the growing season. Understanding total
$\mathrm{N}$ contribution and mineralization rate of organic $\mathrm{N}$ inputs can allow a comparison with crop need.

Organic N management is particularly challenging for high $\mathrm{N}$ requiring crops such as sweet corn. Organic growers typically use a variety of strategies to meet crop $\mathrm{N}$ needs such as using $\mathrm{N}$-fixing legumes as GrM crops, composted manure, and commercially available amendments (Gaskell and Smith, 2007). Composted manure is a cost-effective means of providing $\mathrm{N}$ to an organic crop because of its role as a waste product and relative abundance. However, composted manure presents several challenges for organic sweet corn production. It generally has low $\mathrm{N}$ concentration $(<5 \%)$, so large quantities must be applied (Berry et al., 2002), adding expense in application. Current University of Wisconsin Extension pest management guidelines suggest that manure also should be applied and incorporated at least 1 week in advance of sweet corn planting to reduce seed damage by seed corn maggot [Delia platura (Boerboom et al., 2011)]. Sweet corn does not begin to take up significant quantities of $\mathrm{N}$ until the fiveleaf stage (Doerge et al., 1991), which can take up to 1 month after planting in the upper midwestern United States. Any $\mathrm{N}$ that is mineralized from the manure during this time is vulnerable to loss from leaching or volatilization.

Soil amendments that contain higher concentrations of $\mathrm{N}$ such as feather meal, bone meal, fish powder, and guano are available commercially in various formulations. Smaller total quantities of these amendments can be applied as they have higher $\mathrm{N}$ concentration, ranging $11 \%$ to $14 \%$ (Hartz and Johnstone, 2006), reducing transportation and application costs compared with manure. Hadas and Kautsky (1994) reported continuous release of PAN from feather meal in an 8 week incubation study. Sustained

\begin{tabular}{llll}
\hline $\begin{array}{l}\text { Units } \\
\text { To convert U.S. to SI, } \\
\text { multiply by }\end{array}$ & U.S. unit & SI unit & $\begin{array}{l}\text { To convert SI to U.S., } \\
\text { multiply by }\end{array}$ \\
\hline 0.4047 & $\mathrm{acre}(\mathrm{s})$ & $\mathrm{ha}$ & 2.4711 \\
29,574 & $\mathrm{fl} \mathrm{oz}$ & $\mu \mathrm{L}$ & $3.3814 \times 10^{-5}$ \\
29.5735 & $\mathrm{fl} \mathrm{oz}$ & $\mathrm{mL}$ & 0.0338 \\
2.54 & inch $(\mathrm{es})$ & $\mathrm{cm}$ & 0.3937 \\
0.4536 & $\mathrm{lb}$ & $\mathrm{kg}$ & 2.2046 \\
28.3495 & $\mathrm{oz}$ & $\mathrm{g}$ & 0.0353 \\
1 & $\mathrm{ppm}$ & $\mathrm{mg} \cdot \mathrm{kg}^{-1}$ & 1 \\
$\left({ }^{\circ} \mathrm{F}-32\right) \div 1.8$ & ${ }^{\circ} \mathrm{F}$ & ${ }^{\circ} \mathrm{C}$ & $\left(1.8 \times{ }^{\circ} \mathrm{C}\right)+32$ \\
& & &
\end{tabular}


mineralization throughout the growing season is ideal for a long-season crop such as sweet corn that takes up N over a long period of time. Furthermore, commercially available feather meal amendments are of a granular consistency that can be sidedressed during the growing season. Thus, they can be applied closer to the time of need and initial flushes of mineralized $\mathrm{N}$ can be captured by the crop. However, feather meal amendments tend to be costly; thus, matching amendment mineralization to sweet corn need is important, so less feather meal can be used.

Legumes as a GrM crop can deliver $\mathrm{N}$ to a subsequent cash crop at a low cost to the grower (Tourte et al., 2003 ). Alfalfa can provide a significant $\mathrm{N}$ credit. University of Wisconsin Extension recommendations suggest alfalfa can contribute up to $100 \mathrm{lb} /$ acre on sandy soils (Laboski et al., 2006), if grown for 1 year before incorporation. Peas can also be used as a GrM crop. Although reports vary, extension recommendations from South Dakota suggest the $\mathrm{N}$ credit from peas may be as high as $40 \mathrm{lb} /$ acre (Gerwin and Gelderman, 2005). In some production areas, a pea GrM crop can also be grown in cool spring conditions before sweet corn planting and not require the potential financial sacrifice of 1 year of crop production.

Composted manure and feather meal organic $\mathrm{N}$ mineralization have been studied (Diaz et al., 2008; Hadas and Kautsky, 1994). However, the organic $\mathrm{N}$ mineralization of these amendments in combination with GrM crops has not been investigated, particularly on a loamy sand soil. Soil texture plays a role in soil temperature and water holding capacity and thus affects mineralization rate. There can be as much as a $30 \%$ difference in total $\mathrm{N}$ mineralization of organic matter depending on soil texture (Griffin et al., 2002).

Nitrogen mineralization dynamics are difficult to capture in field settings. This study aimed to understand the mineralization of several GrM crops in combination with soil amendments in a laboratory incubation study. The objectives were to determine PAN from alfalfa, pea, and rye GrM crops alone, two commercially available organic fertilizers, CPM, and the combinations of GrM crops with the fertilizers or manure at six points over a 112-d incubation. The availability of $\mathrm{N}$ was then compared with crop need at points during the growing season to identify GrM crop and amendment mineralization that best matches crop need.

\section{Materials and methods}

Soil with GrM treatments (alfalfa, rye, pea, and no GrM crop) was collected from field plots for a related study (Johnson, 2009) at the Hancock Agricultural Research Station (HARS), Hancock, WI, on 18 June 2007, 1 week after GrM crops had been incorporated into the soil with a field harrow. The soil at HARS is an overhead-irrigated Plainfield loamy sand (mixed, mesic Typic Udipsamment). The specific soil texture in this field was $90 \%$ sand, $3 \%$ silt, and $7 \%$ clay, determined using the hydrometer method (Bouyoucos, 1962). Organic matter was $0.9 \%$, determined by the weight loss-on-ignition method (Schulte and Hopkins, 1996). The $\mathrm{pH}$ was 6.2, using a $\mathrm{pH}$ meter, and phosphorus $(\mathrm{P})$ and potassium $(\mathrm{K})$ levels were 76 and 87 ppm, respectively. Both $\mathrm{P}$ and $\mathrm{K}$ were extracted from the soil with the Bray Pl solution, $\mathrm{P}$ was determined colorimetrically after reacting with ammonium molybdate and $\mathrm{K}$ was determined via atomic adsorption (Bray and Kurtz, 1945). The alfalfa GrM crop was planted 10 Apr. 2006 (2.4 million seeds/acre) and was incorporated 11 June 2007. The pea and rye GrM crops were planted on 22 Apr. 2007 (122,000 seeds/acre and 1 million seeds/acre, respectively) and were incorporated on 11 June 2007. According to current University of Wisconsin Extension recommendations, the alfalfa had enough top growth to receive a $100 \mathrm{lb} /$ acre $\mathrm{N}$ credit at the time of plow down (Laboski et al., 2006). Information on an $\mathrm{N}$ credit associated with pea grown as a GrM crop is not available, so we used the University of South Dakota Extension recommendation of a $40 \mathrm{lb} /$ acre $\mathrm{N}$ credit when pea is grown as the previous crop (Gerwin and Gelderman, 2005). Soil was collected out of a randomly selected area in each plot to a depth of 6 inches and in a 6-inch-diameter circle. The soil was air-dried, and plant material was sieved out of the soils and retained, coarsely chopped with a knife into 0.01 to 0.02 -inch pieces and mixed back into the soil as uniformly as possible.

Composted, pelletized poultry manure was used as a composted manure source for the study. A feather meal based amendment, Organic Nitrogen Fertilizer 11-0-0 (advertised content $11 \mathrm{~N}-0 \mathrm{P}-0 \mathrm{~K}$; Renaissance Fertilizer Co., Rowley, MA), and Organic Garden Fertilizer 5-5-5 (advertised content $5 \mathrm{~N}-2.2 \mathrm{P}-4.2 \mathrm{~K}$, Renaissance Fertilizer Co.), were used as representatives of commercially available organic fertility management products. Ammonium nitrate was used as a conventional control. The CPM and amendment sources were analyzed, on a dry matter basis, for actual macronutrient content. CPM contained $4.4 \% \mathrm{~N}$, $1.8 \% \mathrm{P}$, and $2.5 \% \mathrm{~K}$; Organic Nitrogen Fertilizer 11-0-0 (hereafter referred to as $11-0-0)$ contained $10.1 \% \mathrm{~N}, 0.5 \% \mathrm{P}$, and $0.6 \% \mathrm{~K}$; Organic Garden Fertilizer 5-5-5 (hereafter referred to as 5-5-5) contained $6.1 \% \mathrm{~N}, 1.8 \% \mathrm{P}$, and $4.8 \%$ $\mathrm{K}$; ammonium nitrate contained 34\% $\mathrm{N}$. Treatments were designed to add CPM, 11-0-0, and 5-5-5 to the soils at a rate of $150 \mathrm{lb} /$ acre, the recommended rate of $\mathrm{N}$ application for sweet corn in Wisconsin (Laboski et al., 2006). The amount of CPM applied was determined using the $\mathrm{N}$ content from the laboratory analysis. Organic fertilizers were applied based on advertised $\mathrm{N}$ rates. We made this decision because growers typically have manure analyzed because of variability in macronutrient content. On the other hand, advertised macronutrient content of commercially available amendments is regulated and generally accepted by growers as accurate without further testing.

The study was a completely randomized design with three replications of each soil/amendment combination. There were four cover crop treatments (alfalfa, pea, rye, and none) and five amendment treatments (11-0-0, 5-5-5, CPM, ammonium nitrate, and none), resulting in 20 treatments. Each treatment replication was divided into six equivalent 2 -fl oz plastic cups $(2-3 / 8$ inches top diameter, $1-13 / 16$ inch bottom diameter, 1-3/16 inch tall; Dart Container Corp., Mason, MI) so that an individual cup for each treatment could be removed from the incubator at each sampling date. Each cup consisted of $40 \mathrm{~g}$ of soil with the various amendments. The amendments were chopped into uniformly sized pieces, added to the soil, and mixed thoroughly. We did not grind the amendments because this could increase mineralization rate (compared with 
larger pieces) and not mimic realistic field conditions.

Several small holes were made in the lids of the plastic cups to allow air exchange, the lids were placed on the cups and the cups were placed in a dark growth chamber at $25^{\circ} \mathrm{C}$. The cups were pulled out weekly, weighed, and watered to $50 \%$ of water-filled pore capacity (WFPC). Water-filled pore capacity was determined by the following procedure. Two grams of soil from each of the different GrM programs (none, rye, alfalfa, and pea) were placed in tins and dried in an oven at $30^{\circ} \mathrm{C}$ for $24 \mathrm{~h}$ before weight was recorded. The soil samples were then placed in funnels and watered until saturation. The funnels with soil were allowed to sit for $24 \mathrm{~h}$ before the soil was reweighed. The WFPC of each sample was determined by subtracting the weight of the dry soil from the weight of the wet soil and then dividing this number by the weight of the dry soil. The mean WFPC of all of the samples was used to determine $50 \%$ WFPC for the study. If weed seeds germinated in the cups at any point during the study, they were gently tugged from the soil to discontinue their growth and laid on top of the soil as to not remove any $\mathrm{N}$ from the system (this was rare).

Three replication cups of each treatment were pulled out at $1,2,4$, 8,12 , and 16 weeks. The cup contents were emptied into weigh boats and allowed to air dry for $24 \mathrm{~h}$. Once completely dry, the samples were stored in plastic zip top bags until analysis. Ammonium and nitrate were then determined in all of the samples by extracting $2 \mathrm{~g}$ of soil with $2 \mathrm{M}$ potassium chloride in a $1: 10$ soil to solution ratio and shaking for $15 \mathrm{~min}$ with an orbital shaker at $200 \mathrm{rpm}$. Samples were then immediately filtered through Whatman no. 2 filter paper into 20 -mL glass scintillation vials. A duplicate sample, spiked duplicate, blank, and soil standard were extracted and analyzed every 25 samples for quality assurance. Ammonium and nitrate were analyzed within $24 \mathrm{~h}$ of extraction on a microplate spectrophotometer (PowerWave ${ }^{\mathrm{TM}} \mathrm{XS}$; BioTek Instruments, Winooski, VT). The sodium salicylate-nitroprusside method was adapted for microscale analysis to measure ammonium (Keeney and Nelson, 1982). The single reagent method with vanadium chloride as a reductant was used to measure nitrite and nitrate concentrations although nitrite concentrations were considered negligible and were reported as nitrate (Doane and Horwath, 2003). This method was also adapted to use less reagent, $750 \mu \mathrm{L}$ of reagent for every $15 \mu \mathrm{L}$ of sample extract. The colorimetric reaction occurred in deep welled ( $1 \mathrm{~mL}$ ) microplates before a $250-\mu \mathrm{L}$ aliquot was transferred to the $300-\mu \mathrm{L}$ plates used in the spectrophotometer.

For data analysis, the mean mineralized PAN of the non-amended, non-cropped soil was subtracted from the PAN mineralized from each treatment replication at corresponding dates to represent the net mineralization of the amendment or amendment/ crop combination. A repeated measures analysis of variance (Proc Mixed, SAS version 9.2; SAS Institute, Cary, NC) with an unstructured model (UN) was used to compare the net mean PAN of the treatments. There was a significant date by treatment interaction, so each quantification date was analyzed separately and Tukey's honestly significant difference test was used to make pairwise comparisons between treatments at each date and to compare changes in PAN in individual treatments over time.

\section{Results and discussion}

The total recommended $\mathrm{N}$ fertilizer for sweet corn production is 150 $\mathrm{lb} / \mathrm{acre}$ (Laboski et al., 2006), which is equivalent to $82.5 \mathrm{mg} \cdot \mathrm{kg}^{-1} \mathrm{~N}$. Sweet corn $\mathrm{N}$ uptake primarily occurs from the five-leaf to 12-leaf stages and from just after silking to harvest (Doerge et al., 1991). Correlations between growing degree days [GDD (base $\left.\left.50{ }^{\circ} \mathrm{F}\right)\right]$ and stages of plant development for sweet corn (Johnson, 2009) were used to draw comparisons for this study. The five-leaf stage occurs about between 600 and 700 GDD, silking between 950 and 1150 GDD, and maturity is reached at 1400-1600 GDD. Our incubation study maximum GDD was 3024.

Organic $\mathrm{N}$ mineralization in the non-amended, non-GrM soil was $\approx 30 \mathrm{mg} \cdot \mathrm{kg}^{-1} \mathrm{~N}$ over $112 \mathrm{~d}$ (including PAN already present in soil at the start of the incubation), which is equivalent to $54.5 \mathrm{lb} /$ acre (Fig. 1). More $\mathrm{N}$ was mineralized from the alfalfa GrM than either pea or rye at each sampling date, with the exception of the 14-d quantification (Fig. 2). Total PAN at the end of the incubation in the alfalfa treatment was $43.1 \mathrm{mg} \cdot \mathrm{kg}^{-1} \mathrm{~N}$, which is equivalent to $80 \mathrm{lb} /$ acre. Current University of Wisconsin Extension recommendations report that 1 -year-old alfalfa should be given an $\mathrm{N}$ credit of $100 \mathrm{lb} /$ acre, a slightly higher credit than determined by this study (Laboski et al., 2006). However, $\mathrm{N}$ credit is not only based on the lesser amount of $\mathrm{N}$ fertilizer needed because of the GrM crop but also takes into account the increase in yield often seen because of rotational effect of an alternative legume crop (Stranger et al., 2008). The discrepancy between the present results and current recommendations may be indicative of a rotational effect.

More than half of the $\mathrm{N}$ mineralized from the alfalfa occurred in the first $7 \mathrm{~d}$, while the remainder mineralized by day 84 of sampling (Fig. 2). This mineralization period would coincide with the entire development of a sweet corn crop. However, the majority is released before the period of greatest uptake by the crop and could be subject to loss because of leaching or denitrification. We did not observe a period of $\mathrm{N}$ immobilization as was reported in a laboratory incubation study with legume GrM crops that included devil bean (Crotalaria retusa), sunn hemp (Crotalaria juncea), and velvet bean (Mucuna pruriens) on a loamy sand soil (Fosu et al., 2007). Those authors reported that the legumes did not release $\mathrm{N}$ until day 24 of incubation and in the case of the devil bean, there was no net $\mathrm{N}$ release observed within the time period of the study. Although an alfalfa GrM crop contributed significantly to the total sweet corn $\mathrm{N}$ demand $(150 \mathrm{lb} /$ acre), supplemental $\mathrm{N}$ would still be needed for sweet corn production.

The $\mathrm{N}$ mineralized from the pea GrM was comparable to rye at every date, suggesting it should not receive any $\mathrm{N}$ credit (Fig. 2). This may be because the pea did not fix any $\mathrm{N}$; it simply used $\mathrm{N}$ already in the soil, similar to the rye. Typically, this would suggest a lack of nodulation. However, nodulation was checked and confirmed in the field in Spring 2007. Furthermore, the peas were allowed to grow for $48 \mathrm{~d}$ and there was a median average soil temperature of $\approx 19^{\circ} \mathrm{C}$ at the Hancock Research Station (at $5 \mathrm{~cm}$ below soil surface; data not shown). Several studies have reported nodulation to start in peas optimally at between 15 and $20{ }^{\circ} \mathrm{C}$ and within 


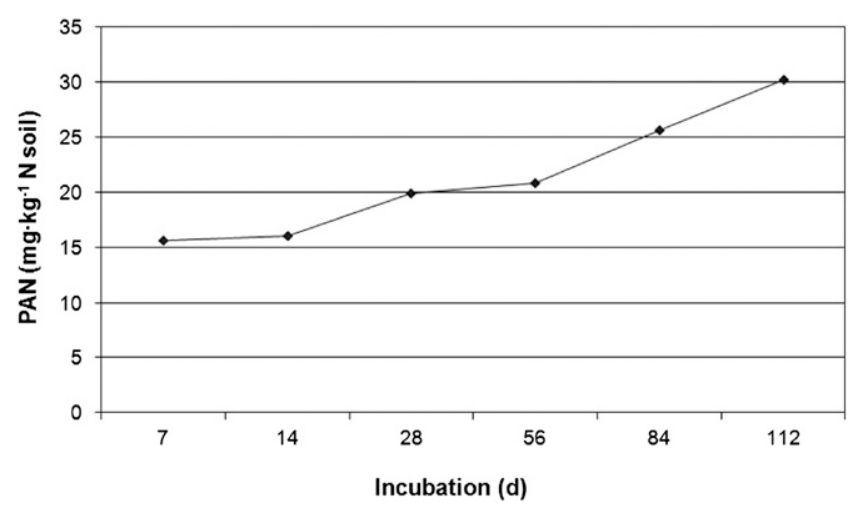

Fig. 1. Plant available nitrogen [PAN (ammonium + nitrate)] mineralized from non-cropped, non-amended soil over time in laboratory incubation study; $1 \mathrm{mg} \cdot \mathrm{kg}^{-1}=1 \mathrm{ppm}$.

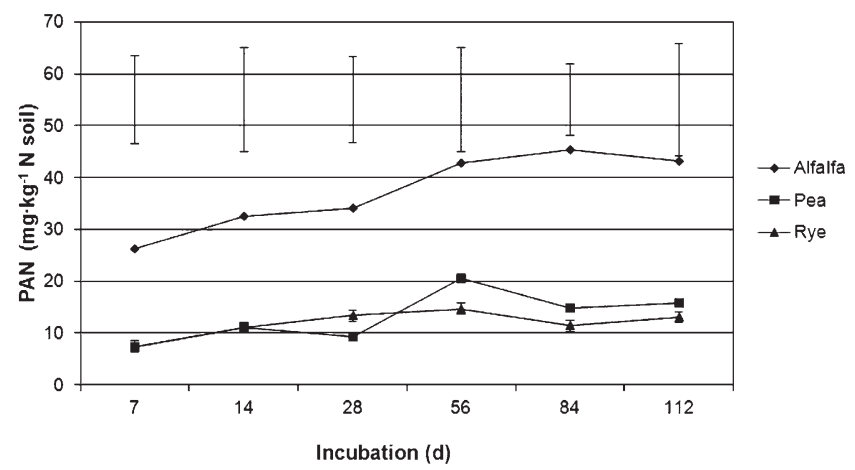

Fig. 2. Net plant available nitrogen [PAN (ammonium + nitrate)] mineralized from green manure (GrM) crops (alfalfa, pea, and rye) over time in incubation study (PAN mineralized from non-amended, non-cropped soil was subtracted from PAN from each treatments at each date). SE bars represent differences among GrM treatments within each sampling date. Mean separation lowercase letters represent differences within treatments over dates. Among and across date means were separated at a significance level of $\boldsymbol{P}=\mathbf{0 . 0 5}$, using Tukey's honestly significant difference test; $1 \mathrm{mg} \cdot \mathrm{kg}^{-1}=1 \mathrm{ppm}$.

$40 \mathrm{~d}$ after planting (Herdina and Silsbury, 1989; Naeem et al., 2008). However, the duration between nodulation and plow-down may not have been sufficient to produce significant amounts of $\mathrm{N}$ or the nodules may not have been active. Nodulation and $\mathrm{N}$ fixation by pea grown as a GrM in this soil type should be further studied.

The ammonium nitrate was already in plant-available form at application. The PAN at $7 \mathrm{~d}$ of incubation was nearly $100 \%$ of the applied concentration $\left(82.5 \mathrm{mg} \cdot \mathrm{kg}^{-1} \mathrm{~N}\right)$ (Table $\left.\mathrm{l}\right)$. The fact that the PAN concentrations are slightly lower than the amount applied reflects that detection may be slightly lower than reality or potentially indicate denitrification losses or microbial utilization. The percent of the PAN that was ammonium was slightly less than half at $7 \mathrm{~d}$ but rapidly diminished at successive quantification dates until almost complete conversion to nitrate at $56 \mathrm{~d}$. The PAN remaining in the soil at this period would be highly susceptible to leaching. For this reason, conventional fertilizer recommendations include sidedressing in split applications to match soil concentration with plant need and reduce $\mathrm{N}$ loss to leaching (Wolkowski et al., n.d.).

The PAN mineralized from the CPM increased at successive quantification dates until day 28 when the level remained between $\approx 60$ and $66 \mathrm{mg} \cdot \mathrm{kg}^{-1}$ $\mathrm{N}$ (Table $\mathrm{l}$ ). This rate of mineralization from the CPM fairly closely matched sweet corn demand. The greatest increase in mineralization rate occurred between 14 and $28 \mathrm{~d}$ of incubation (378-756 GDD). This corresponds with just before the five-leaf sweet corn stage to just before silking. Based on the data, the PAN from CPM would be available for sweet corn use just before the period of highest $\mathrm{N}$ use. However, under field conditions, CPM would be applied and incorporated 1 week or more before planting. Thus, in a field setting, the mineralization of PAN from CPM would precede sweet corn need and the nitrate portion would be vulnerable to leaching. Fortunately, $64 \%$ of the PAN was still in the nonleaching ammonium form at $14 \mathrm{~d}(378$ GDD). This asynchrony between PAN mineralization from CPM and sweet corn $\mathrm{N}$ need was also observed when a full $\mathrm{N}$ rate of CPM was used for sweet corn production in the field (Johnson, 2009). The authors observed high PAN concentrations in the soil before sweet corn five-leaf stage in 2 out of 3 years of the study. A combination of $\mathrm{N}$ mineralization before crop need and heavy precipitation leaching events could cause PAN loss and subsequently $\mathrm{N}$ deficiency for the crop.

At the end of the study, PAN from the CPM was equivalent to the ammonium nitrate treatment, suggesting it was mostly available in the first growing season (Tablel). Composted poultry manure $\mathrm{N}$ availability during the first year has been reported to range from $14 \%$ to $60 \%$ of total N applied (Muñoz et al., 2008). However, mineralization was likely greater on the loamy sand soils of Wisconsin. Soil texture can affect manure or compost mineralization, with as much as 99\% $\mathrm{N}$ availability from manure on coarse textured soils in comparison with $62 \%$ on silt loam soil in an incubation study (Griffin et al., 2002). Environmental differences in temperature and soil moisture also may alter the availability among years (Gaskell and Smith, 2007).

A secondary complication with using CPM for organic production is the high $\mathrm{P}$ content of manure. Applying CPM at a rate that would apply sufficient $\mathrm{N}$ to a sweet corn crop would overapply P. Soils with excessively high $\mathrm{P}$ concentration can contribute to eutrophication of surface water through surface water runoff (Correll, 1998). This suggests that the sole utilization of CPM for organic production is not an environmentally sustainable tactic and $\mathrm{P}$ content should be kept in mind when designing organic fertility management systems.

The PAN concentration of the soil amended with 5-5-5 was similar from 28 to $112 \mathrm{~d}$ with only $\approx 65 \%$ of the total organic $\mathrm{N}$ applied mineralized 
Table 1. Plant available nitrogen (PAN), mineralized from green manure (GrM)-cropped soil with each amendment at successive days of incubation. Non-cropped, non-amended soil PAN was subtracted from each treatment at each sampling date.

\begin{tabular}{|c|c|c|c|c|c|c|c|c|c|}
\hline \multirow[b]{3}{*}{ Time $(d)$} & \multirow[b]{3}{*}{ Amendment $^{\mathrm{z}}$} & \multicolumn{8}{|c|}{ GrM crop } \\
\hline & & \multicolumn{2}{|l|}{ None } & \multicolumn{2}{|l|}{ Alfalfa } & \multicolumn{2}{|l|}{ Pea } & \multicolumn{2}{|l|}{ Rye } \\
\hline & & $\begin{array}{c}\text { PAN } \\
\left(\mathrm{mg} \cdot \mathrm{kg}^{-1} \mathrm{~N}\right)^{\mathrm{y}}\end{array}$ & $\begin{array}{c}\mathrm{NH}_{4} \\
(\%)^{\mathrm{x}}\end{array}$ & $\begin{array}{c}\mathrm{PAN} \\
\left(\mathrm{mg} \cdot \mathrm{kg}^{-1} \mathrm{~N}\right)\end{array}$ & $\begin{array}{c}\mathrm{NH}_{4} \\
(\%) \\
\end{array}$ & $\begin{array}{c}\text { PAN } \\
\left(\mathrm{mg} \cdot \mathrm{kg}^{-1} \mathrm{~N}\right)\end{array}$ & $\begin{array}{c}\mathrm{NH}_{4} \\
(\%) \\
\end{array}$ & $\begin{array}{c}\text { PAN } \\
\left(\mathrm{mg} \cdot \mathrm{kg}^{-1} \mathrm{~N}\right)\end{array}$ & $\begin{array}{c}\mathrm{NH}_{4} \\
(\%) \\
\end{array}$ \\
\hline \multirow[t]{4}{*}{$7(189 \text { GDD })^{w}$} & $\mathrm{NH}_{4} \mathrm{NO}_{3}$ & $74.4 \mathrm{a}^{\mathrm{v}}(\mathrm{A})^{\mathrm{u}}$ & 42 & $101.7 \mathrm{a}(\mathrm{A})$ & 44 & 79.8 a (A) & 44 & $12.6 \mathrm{c}(\mathrm{A})$ & 2 \\
\hline & $\mathrm{CPM}$ & $23.7 \mathrm{~b}(\mathrm{~A})$ & 86 & $57.4 \mathrm{~b}(\mathrm{~A})$ & 62 & 29.3 bc $(\mathrm{A})$ & 61 & 45.7 a $(\mathrm{A})$ & 67 \\
\hline & $5-5-5$ & $34.5 \mathrm{~b}(\mathrm{~A})$ & 81 & $47.7 \mathrm{~b}(\mathrm{~A})$ & 32 & $37.0 \mathrm{~b}(\mathrm{~A})$ & 67 & $47.4 \mathrm{a}(\mathrm{A})$ & 69 \\
\hline & $11-0-0$ & $16.2 \mathrm{c}(\mathrm{A})$ & 93 & 38.8 bc $(\mathrm{A})$ & 61 & $17.9 \mathrm{c}(\mathrm{A})$ & 73 & $25.9 \mathrm{~b}(\mathrm{~A})$ & 78 \\
\hline \multirow[t]{4}{*}{14 (378 GDD) } & $\mathrm{NH}_{4} \mathrm{NO}_{3}$ & 79.2 a $(\mathrm{A})$ & 27 & $112.4 \mathrm{a}(\mathrm{AB})$ & 33 & 84.5 a $(\mathrm{A})$ & 30 & $22.7 \mathrm{~b}(\mathrm{~A})$ & 13 \\
\hline & CPM & $30.0 \mathrm{~b}(\mathrm{~B})$ & 64 & $94.8 \mathrm{ab}(\mathrm{B})$ & 42 & $55.2 \mathrm{~b}(\mathrm{~B})$ & 20 & $54.4 \mathrm{a}(\mathrm{A})$ & 48 \\
\hline & $5-5-5$ & $28.9 \mathrm{~b}(\mathrm{AB})$ & 71 & $67.9 \mathrm{c}(\mathrm{B})$ & 5 & $56.4 \mathrm{~b}(\mathrm{~B})$ & 36 & $54.1 \mathrm{a}(\mathrm{AB})$ & 34 \\
\hline & $11-0-0$ & $65.0 \mathrm{a}(\mathrm{B})$ & 49 & $71.9 \mathrm{bc}(\mathrm{B})$ & 52 & $46.8 \mathrm{~b}(\mathrm{~B})$ & 55 & 58.7 a $(\mathrm{B})$ & 67 \\
\hline \multirow[t]{4}{*}{28 (756 GDD) } & $\mathrm{NH}_{4} \mathrm{NO}_{3}$ & 76.2 a $(\mathrm{A})$ & 17 & $120.2 \mathrm{a}(\mathrm{AB})$ & 24 & $86.2 \mathrm{a}(\mathrm{A})$ & 13 & $24.0 \mathrm{c}(\mathrm{A})$ & 0 \\
\hline & $\mathrm{CPM}$ & $58.6 \mathrm{~b}(\mathrm{C})$ & 15 & 89.1 b (BC) & 20 & $70.8 \mathrm{ab}(\mathrm{BC})$ & 2 & $60.0 \mathrm{~b}(\mathrm{~A})$ & 27 \\
\hline & $5-5-5$ & $47.6 \mathrm{~b}(\mathrm{ABC})$ & 5 & $87.3 \mathrm{~b}(\mathrm{C})$ & 7 & $54.5 \mathrm{c}(\mathrm{B})$ & 4 & $57.8 \mathrm{~b}(\mathrm{AB})$ & 19 \\
\hline & $11-0-0$ & $57.7 \mathrm{~b}(\mathrm{~B})$ & 14 & $91.8 \mathrm{~b}(\mathrm{C})$ & 32 & 69.6 bc $(\mathrm{C})$ & 15 & 85.3 a $(\mathrm{CD})$ & 40 \\
\hline \multirow[t]{4}{*}{56 (1512 GDD) } & $\mathrm{NH}_{4} \mathrm{NO}_{3}$ & 78.9 a $(\mathrm{A})$ & 2 & $114.0 \mathrm{a}(\mathrm{AB})$ & 6 & 86.1 a $(\mathrm{A})$ & 4 & $29.4 \mathrm{c}(\mathrm{A})$ & 1 \\
\hline & CPM & $66.3 \mathrm{ab}(\mathrm{C})$ & 1 & $96.2 \mathrm{ab}(\mathrm{BC})$ & 3 & $76.8 \mathrm{ab}(\mathrm{C})$ & 1 & $70.7 \mathrm{~b}(\mathrm{~A})$ & 1 \\
\hline & $5-5-5$ & $55.0 \mathrm{~b}(\mathrm{BC})$ & 1 & $92.1 \mathrm{~b}(\mathrm{CD})$ & 1 & $67.1 \mathrm{~b}(\mathrm{BC})$ & 3 & $70.5 \mathrm{~b}(\mathrm{BC})$ & 2 \\
\hline & $11-0-0$ & $67.8 \mathrm{ab}(\mathrm{BC})$ & 3 & $103.5 \mathrm{ab}(\mathrm{C})$ & 2 & $77.9 \mathrm{ab}(\mathrm{C})$ & 2 & $101.3 \mathrm{a}(\mathrm{D})$ & 12 \\
\hline \multirow[t]{4}{*}{84 (2268 GDD) } & $\mathrm{NH}_{4} \mathrm{NO}_{3}$ & $75.2 \mathrm{a}(\mathrm{A})$ & 0 & $116.1 \mathrm{a}(\mathrm{AB})$ & 2 & $90.9 \mathrm{~b}(\mathrm{~A})$ & 0 & $30.3 \mathrm{~b}(\mathrm{~A})$ & 0 \\
\hline & CPM & 66.1 a $(\mathrm{C})$ & 0 & $96.1 \mathrm{~b}(\mathrm{BC})$ & 2 & 73.8 c $(\mathrm{C})$ & 0 & 67.9 a $(\mathrm{A})$ & 0 \\
\hline & 5-5-5 & 60.9 a $(\mathrm{C})$ & 0 & $96.2 \mathrm{~b}(\mathrm{CD})$ & 1 & $66.5 \mathrm{c}(\mathrm{BC})$ & 0 & $69.3 \mathrm{a}(\mathrm{BC})$ & 0 \\
\hline & $11-0-0$ & 74.6 a $(\mathrm{C})$ & 0 & $105.7 \mathrm{ab}(\mathrm{C})$ & 2 & 113.6 a (D) & 1 & 81.8 a $(\mathrm{C})$ & 2 \\
\hline \multirow[t]{4}{*}{$112(3024$ GDD $)$} & $\mathrm{NH}_{4} \mathrm{NO}_{3}$ & $76.2 \mathrm{a}(\mathrm{A})$ & 0 & $132.1 \mathrm{a}(\mathrm{B})$ & 2 & $98.0 \mathrm{a}(\mathrm{A})$ & 0 & $28.6 \mathrm{c}(\mathrm{A})$ & 0 \\
\hline & CPM & $64.8 \mathrm{ab}(\mathrm{C})$ & 0 & $118.2 \mathrm{ab}(\mathrm{C})$ & 0 & $80.8 \mathrm{ab}(\mathrm{C})$ & 0 & $71.5 \mathrm{~b}(\mathrm{~A})$ & 0 \\
\hline & 5-5-5 & $54.2 \mathrm{~b}(\mathrm{BC})$ & 0 & $107.0 \mathrm{~b}(\mathrm{D})$ & 0 & $78.0 \mathrm{~b}(\mathrm{C})$ & 0 & 80.8 b (C) & 2 \\
\hline & $11-0-0$ & $56.4 \mathrm{ab}(\mathrm{B})$ & 0 & $103.3 \mathrm{~b}(\mathrm{C})$ & 0 & $81.5 \mathrm{ab}(\mathrm{C})$ & 0 & 102.6 a (D) & 2 \\
\hline
\end{tabular}

${ }^{\mathrm{z}} \mathrm{GDD}=$ growing degree days, $\mathrm{NH}_{4} \mathrm{NO}_{3}=$ ammonium nitrate, $\mathrm{CPM}=$ composted, pelletized poultry manure, 5-5-5 = Organic Garden Fertilizer 5-5-5 (advertised content $5 \mathrm{~N}-2.2 \mathrm{P}-4.2 \mathrm{~K}$, Renaissance Fertilizer Co., Rowley, MA), 11-0-0 = Organic Nitrogen Fertilizer 11-0-0 (advertised content 11N-0P-0K; Renaissance Fertilizer Co.).

yPAN includes ammonium and nitrate nitrogen $(\mathrm{N}) ; 1 \mathrm{mg} \cdot \mathrm{kg}^{-1}=1 \mathrm{ppm}$.

xPercentage of total $\mathrm{PAN}$ in $\mathrm{NH}_{4}$ (ammonium) form.

"Growing degree days at base $50^{\circ} \mathrm{F}\left(10.0^{\circ} \mathrm{C}\right)$.

"Treatment means within columns (individual green manure (GrM) crops in combination with each amendment), within incubation times, were compared and means separated using Tukey's honestly significant difference test. Means followed by the same lowercase letter are not significantly different at $P=0.05$.

"Individual treatment means within a column (individual GrM crops in combination with each amendment), across incubation times were compared and means separated using Tukey's honestly significant difference test. Means followed by the same capitalized letter are not significantly different at $P=0.05$.

from $5-5-5$ by the end of the study (Table 1). This suggests that 5-5-5 would not completely mineralize during a growing season. This fertilizer also has nearly equivalent amounts of $\mathrm{P}$ and $\mathrm{N}$, so it does not resolve the problem of $\mathrm{P}$ overapplication encountered with CPM. Furthermore, the actual $\mathrm{N}$ content of this amendment was $25 \%$ greater than the reported $\mathrm{N}$ content. Thus, if a grower applied 5-55 based on actual macronutrient content, less of the amendment would be applied and correspondingly lower amounts of PAN would be available to the crop.

The PAN concentration mineralized from 11-0-0 was less than all of the other amendments in the first $7 \mathrm{~d}$ (Table 1). Significant mineralization occurred between 7 and $14 \mathrm{~d}$ of incubation and total PAN from 11-0-0 was comparable to the ammonium nitrate treatment by the 14-d sampling. Hadas and Kautsky (1994) reported that only $65 \%$ of the organic $\mathrm{N}$ in feather meal mineralized in an 8 -week, $30{ }^{\circ} \mathrm{C}$ incubation study using a clay soil. This difference highlights the impact of soil texture on mineralization. Perhaps problematically, the $\mathrm{N}$ in 11-0-0 fully mineralized before crop need. However, 11-0-0 can be sidedressed during the growing season to better match $\mathrm{N}$ mineralization with crop need. The rate of PAN availability would closely match crop need if 11-0-0 was sidedressed just before the five-leaf stage (600-700 GDD). In a related field study, this amendment was sidedressed at the five-leaf sweet corn stage (Johnson, 2009). The authors reported similar soil PAN concentration in the treatment that used 11-0-0 exclusively as a nitrogen source and the PAN of the soil in the control (no added N). The sweet corn likely used the $\mathrm{N}$ as soon as it was mineralized from the 11-0-0. The results of this laboratory incubation study and related field study suggest that 11-0-0 is a good option for $\mathrm{N}$ management in organic sweet corn. However, this amendment is costly, so using it in combination with GrM 
may optimize $\mathrm{N}$ while reducing cost to the grower.

Similar to the 5-5-5, the actual N content of 11-0-0 was different from reported. Rather than containing more than reported, the $\mathrm{N}$ content was $0.08 \%$ less. Thus, if actual nutrient content of 11-0-0 had been used to determine application rate, we may have seen higher PAN over the course of the incubation study. Under realistic circumstances, this could have resulted in a grower applying less $\mathrm{N}$ than expected. This highlights variability in batches of packaged amendments that could result in potential $\mathrm{N}$ deficiency.

Plant available $\mathrm{N}$ from the ammonium nitrate in combination with the pea and rye GrM reached a maximum by the 7 -d sampling, while the PAN from the ammonium nitrate with alfalfa GrM was not maximized until the final sampling (Table 1). Because the PAN from alfalfa alone reached a maximum at day 14 , this suggests that a combination with the ammonium nitrate potentially reduced the alfalfa mineralization rate. The total amount of PAN mineralized from the ammonium nitrate and the alfalfa at the end of the incubation study was in excess of a sweet corn crop total season $\mathrm{N}$ need. This reaffirms that the rate of ammonium nitrate could be correspondingly reduced to compensate for a significant alfalfa $\mathrm{N}$ credit of $80 \mathrm{lb} / \mathrm{acre}$ on this particular soil texture. The PAN of pea and ammonium nitrate at the end of the study was slightly higher than the total needed for a sweet corn crop but seemingly not enough to justify an $\mathrm{N}$ credit for the pea GrM crop (Table 1).

Interestingly, when the rye was in combination with the ammonium nitrate, there was substantially less total PAN concentration at each of the dates in comparison with the rye in combination with the other amendments (Table 1), and moreover the rye and ammonium nitrate separately (Table 1). This was most likely attributable to the generally high carbon (C) to $\mathrm{N}$ ratio $(\mathrm{C}: \mathrm{N})$ of rye residue (although we did not determine the $\mathrm{C}$ and $\mathrm{N}$ of the rye residue in this study). The microbial community will draw any soil available $\mathrm{N}$ in the proportion to make use of available carbon, decreasing PAN in the soil. The $\mathrm{C}: \mathrm{N}$ ratio of rye can range anywhere from 11:1 to 55:1 depending on the rye growth stage (Clark et al., 1997). A C:N ratio of greater than $25: 1$ will immobilize PAN in the soil (Allison, 1966). Carbon and $\mathrm{N}$ analysis of a GrM before incorporation would help to determine probability of immobilization. Interestingly, there was no evidence of PAN immobilization from a rye cover crop in field studies that used ammonium nitrate as a fertilizer for sweet corn production (Cline and Silvernail, 2002; Johnson, 2009). Both studies attained optimal sweet corn yield, which would not have been possible if the $\mathrm{N}$ was immobilized and not available for crop use. However, this laboratory incubation suggests that it is possible for rye residue decomposition by soil microbes to cause a decrease in PAN. Growers must account for this when using rye as a GrM.

There were also some interactions when 5-5-5, 11-0-0, and CPM were combined with the GrM crops. The CPM mineralized faster when combined with the alfalfa (Table 1) than the CPM alone (Table 1). Plant available $\mathrm{N}$ of the alfalfa and CPM combined was comparable to the PAN of the ammonium nitrate and alfalfa at $14 \mathrm{~d}$ into the incubation. As with CPM alone (Table 1), mineralization was asynchronous with crop need. The PAN concentration in the alfalfa and organic 11-0-0 peaked at $28 \mathrm{~d}$ of incubation, whereas the organic 11-0-0 alone peaked at $14 \mathrm{~d}$. This suggests that the alfalfa combined with 11-0-0 fertilizer slowed the fertilizer mineralization. Reduced mineralization rate of 11-0-0 fertilizer with the alfalfa would be favorable because $\mathrm{N}$ would be continuously available up to 1512 GDD, coinciding with sweet corn harvest. Furthermore, $32 \%$ of the PAN was in the ammonium form at $28 \mathrm{~d}$ in the alfalfa and organic 11-0-0 treatment, compared with $20 \%$ in the CPM with alfalfa treatment. This could further reduce $\mathrm{N}$ loss as a result of leaching.

The total PAN concentrations at the end of the study period for the organic amendments and pea were sufficient for optimal sweet corn development. These results also confirm that pea grown as a GrM crop should not be given an $\mathrm{N}$ credit as the final PAN concentrations of pea combined with the organic amendments were similar to the final PAN concentrations of the organic amendments with rye.
A diversified strategy for $\mathrm{N}$ management in organic systems can be effective in crops with high $\mathrm{N}$ needs such as sweet corn. Alfalfa provided a significant $\mathrm{N}$ credit and slowed the mineralization of 11-0-0 organic fertilizer to match the seasonal $\mathrm{N}$ use of sweet corn. The 11-0-0 can be sidedressed to draw out the period of $\mathrm{N}$ mineralization in the growing season as well. Although CPM mineralized completely, it mineralized too quickly and was asynchronous with crop demand.

\section{Literature cited}

Allison, F.E. 1966. The fate of nitrogen applied to soils. Adv. Agron. 18:219-258.

Berry, P.M., R. Sylvester-Bradley, I. Phillips, D.J. Hatch, S.P. Cuttle, F.W. Rayns, and P. Gosling. 2002. Is the productivity of organic farms restricted by the supply of nitrogen? Soil Use Mgt. 18:248-255.

Boerboom, C.M., L.G. Bundy, A.J. Bussan, J.B. Colquhoun, E.M. Cullen, K.A. Delahaut, R.L. Groves, C.A.M. Laboski, D.L. Mahr, and W.R. Stevenson. 2011. Wisconsin's Vegetable Production Guide. Univ. of Wisconsin Ext. Publ. A3422. 12 Oct. 2011. <http://learningstore.uwex. edu/Commercial-Vegetable-Productionin-Wisconsin2009-P540C0.aspx> .

Bouyoucos, G.J. 1962. Hydrometer method improved for making particle size analysis of soils. Agron. J. 54:464-465.

Bray, R.H. and L.T. Kurtz. 1945. Determination of total organic and available form of phosphorous and potassium in soil. Soil Sci. 59:39-45.

Clark, A.J., A.M. Decker, J.J. Meisinger, and M.S. McIntosh. 1997. Kill date of vetch, rye, and a vetch-rye mixture I. Cover crop and corn nitrogen. Agron. J. 89:434-441.

Cline, G.R. and A.F. Silvernail. 2002. Effects of cover crop, nitrogen and tillage on sweet corn. HortTechnology 12:118-125.

Correll, D.L. 1998. The role of phosphorus in the eutrophication of receiving waters: A review. J. Environ. Qual. 27:261-266.

Crew, T.E. and M.B. Peoples. 2005. Can the synchrony of nitrogen supply and the crop demand be improved in legume and fertilizer-based agroecosystems? A review. Nutr. Cycl. Agroecosyst. 72:101-120.

Diaz, D.A.R., J.E. Sawyer, and J.P. Mallarino. 2008. CPM supply of potentially available nitrogen with soil incubation. Agron. J. 100:1310-1317.

Doane, T.A. and W.R. Horwath. 2003. Spectrophotometric determination of 
nitrate with a single reagent. Anal. Lett. 36:2713-2722.

Doerge, T.A., R.L. Roth, and B.R. Gardner. 1991. Nitrogen Fertilizer Management in Arizona: Sweet Corn. 12 Oct. 2011. <http://ag.arizona.edu/crops/ soils/nitfertmgtAZ.pdf>.

Fosu, M., R.F. Kühne, and P.L.G. Vlek. 2007. Mineralization and microbial biomass dynamics during decomposition of four leguminous residues. J. Biol. Sci. 7:632-637.

Gaskell, M. and R. Smith. 2007. Nitrogen sources for organic vegetable crops. HortTechnology 17:431-441.

Gerwin, J. and R. Gelderman. 2005. South Dakota Fertilizer Recommendations Guide. 12 Oct. 2011. <http://agbiopubs. sdstate.edu/articles/EC750.pdf>.

Griffin, T.S., C.W. Honeycutt, and Z. He. 2002. Effects of temperature, soil water status and soil type on swine slurry nitrogen transformations. Biol. Fertil. Soils 36:442-446.

Hadas, A. and L. Kautsky. 1994. Feathermeal, a semi-slow-release nitrogen fertilizer for organic farming. Fert. Res. 38:165-170.

Hartz, T.K., J.P. Mitchell, and C. Giannini. 2000. Nitrogen and carbon mineralization dynamic of manures and composts. HortScience 35:209-212.

Hartz, T.K. and P.R. Johnstone. 2006. Nitrogen availability from high-nitrogen containing organic fertilizers. HortTechnology 16:39-42.

Herdina and J.H. Silsbury. 1989. Nodulation and early growth of faba bean (Vicia faba L.) and pea (Pisum sativum L.) as affected by strain of Ryzobium, $\mathrm{NO}_{3}{ }^{-}$supply and growth temperature. Aust. J. Agr. Res. 40:991-1001.

Johnson, H.J. 2009. Feasibility of organic production of sweet corn and snap beans for processing. Univ. of Wisconsin, Madison, PhD Diss.

Keeney, D.R. and D.W. Nelson. 1982. Nitrogen-inorganic forms, p. 643-698. In: A.L. Page (ed.). Methods of soil analysis. Part 2. Chemical and microbiological processes. Amer. Soc. Agron., Soil Sci. Soc. of Amer., Madison, WI.

Laboski, C.A.M., J.P. Peters, and L.G. Bundy. 2006. Nutrient Application Guides for Field, Vegetable, and Fruit Crops in Wisconsin. Univ. of Wisconsin Ext. Publ. A2809. 12 Oct. 2011. $<$ http://learningstore.uwex.edu/ Nutrient-Application-Guidelines-forField-Vegetable-and-Fruit-Crops-inWisconsin-P185C0.aspx $>$.
Muñoz, G.R., K.A. Kelling, K.E. Rylant, and J. Zhu. 2008. Field evaluation of nitrogen availability from fresh composted manure. J. Environ. Qual. 37:944-955.

Naeem, F., K.A. Malik, and F.Y. Hafeez. 2008. Pisum satioum-Rhyzobium interactions under different environmental stresses. Pak. J. Bot. 40:2601-2612.

Schulte, E.E. and B.G. Hopkins. 1996. Estimation of soil organic matter by weight-loss-on-ignition, p. 21-31. In: F.R. Magdoff, M.A. Tabatabai, and E.A. Hanlon, Jr. (eds.). Soil organic matter: Analysis and interpretation. Soil Sci. Soc. Amer., Madison, WI.

Stranger, T.F., J.G. Lauer, and J.P. Chavas. 2008. The profitability and risk of longterm cropping systems featuring different rotations and nitrogen rates. Agron. J. 100:105-113.

Tourte, L., M. Buchanan, K. Klonsky, and D. Mountjoy. 2003. Estimated Costs and Potential Benefits for an Annually Planted Cover Crop. 24 Oct. 2011. <http:// www.awqa.org/pubs/CostEstimates/ PlantedCoverCrop.pdf $>$.

Wolkowski, R.P., K.A. Kelling, and L.G. Bundy. n.d. Nitrogen Management on Sandy Soils. Univ. of Wisconsin Ext. Publ. A3634. 12 Oct. 2011. <http:// learningstore.uwex.edu/pdf/A3634.pdf>. 